\title{
Osmium tetroxide as a probe of RNA structure
}

\author{
JING ZHANG, ${ }^{1,2,3}$ DANBIN LI, ${ }^{3}$ JUN ZHANG, ${ }^{3}$ DONGRONG CHEN, ${ }^{1,2,3}$ and ALASTAIR I.H. MURCHIE ${ }^{1,2,3}$ \\ ${ }^{1}$ Fudan University Pudong Medical Center, Pudong, Shanghai 201399, China \\ ${ }^{2}$ Key Laboratory of Metabolism and Molecular Medicine, Ministry of Education, School of Basic Medical Sciences, Fudan University, \\ Shanghai 200032, China \\ ${ }^{3}$ Institute of Biomedical Sciences, Shanghai Medical College, Fudan University, Shanghai 200032, China
}

\begin{abstract}
Structured RNAs have a central role in cellular function. The capability of structured RNAs to adopt fixed architectural structures or undergo dynamic conformational changes contributes to their diverse role in the regulation of gene expression. Although numerous biophysical and biochemical tools have been developed to study structured RNAs, there is a continuing need for the development of new methods for the investigation of RNA structures, especially methods that allow RNA structure to be studied in solution close to its native cellular conditions. Here we use osmium tetroxide $\left(\mathrm{OsO}_{4}\right)$ as a chemical probe of $\mathrm{RNA}$ structure. In this method, we have used fluorescence-based sequencing technologies to detect $\mathrm{OsO}_{4}$ modified $\mathrm{RNA}$. We characterized the requirements for $\mathrm{OsO}_{4}$ modification of RNA by investigating three known structured RNAs: the M-box, glycine riboswitch $\mathrm{RNAs}$, and $\mathrm{RNNA}^{\text {asp }}$. Our results show that $\mathrm{OsO}_{4}$ predominantly modifies $\mathrm{RNA}$ at uracils that are conformationally exposed on the surface of the RNA. We also show that changes in $\mathrm{OsO}_{4}$ reactivity at flexible positions in the RNA correlate with ligand-driven conformational changes in the RNA structure. Osmium tetroxide modification of RNA will provide insights into the structural features of RNAs that are relevant to their underlying biological functions.
\end{abstract}

Keywords: chemical probe; osmium tetroxide; RNA; RNA structure

\section{INTRODUCTION}

Structured RNAs have key roles in the regulation of gene expression. Novel RNA classes have been identified, including riboswitches, microRNAs, and promoter- or termini-associated short RNAs and large intergenic noncoding RNAs (lincRNAs) of unknown function (Ambros 2001; Kapranov et al. 2007; Guttman et al. 2009; Mauger and Weeks 2010). An important aspect of the function of regulatory RNA molecules is the intrinsic capacity of the structured RNA to undergo dynamic changes in response to fluctuations in cellular conditions (Cruz and Westhof 2009; Dethoff et al. 2012). A number of enzyme and chemical probing methods have been developed to study RNA structures in solution (Tijerina et al. 2007; Mauger and Weeks 2010; Weeks 2010; Westhof and Romby 2010). Chemical probes are usually small, can access RNA with little steric hindrance, and react with RNA in a structure-specific manner. They can also be used under conditions in which enzymes would not be functional. Certain RNA structures may not be accessible to relatively bulky enzyme probes, and enzymes may also induce anomalous structures in RNA. In general, structural information can be inferred from the relative reactivities of particular nucleotides toward the chemical probe. Typically, chemical

Corresponding authors: aihm@fudan.edu.cn, drchen@fudan.edu.cn Article is online at http://www.rnajournal.org/cgi/doi/10.1261/rna. 057539.116. probes react at single-stranded or "flexible" regions in RNA (Soukup and Breaker 1999; Wilkinson et al. 2006; Tijerina et al. 2007). Probing techniques such as "in-line" probing (Soukup and Breaker 1999), SHAPE (selective 2'-hydroxyl acylation analyzed by primer extension) (Wilkinson et al. 2006; Kenyon et al. 2014), and hydroxyl radical footprinting (Tullius and Greenbaum 2005; Shcherbakova et al. 2006) that probe access to the sugar phosphate backbone of the RNA have been used to map the structural transitions of regulatory RNA molecules at nucleotide resolution (Dann et al. 2007). Additional chemical probes for RNA include DMS, diethyl pyrocarbonate, 1-cyclohexyl-3-(2-morpholinoethyl) carbodiimide metho-p-toluene sulfonate, and kethoxal (for review, see Tijerina et al. 2007; Weeks 2010; Xu and Culver 2013). Such probing methods provide complementary data to enzyme probes for the analysis of RNA structures (for review, see Tijerina et al. 2007; Weeks 2010). By their nature, each probe explores different aspects of the tertiary structure of the RNA because different positions on the nucleosides are targeted. For these reasons there is always a requirement for the development of new chemical probing methods to study

(C) 2017 Zhang et al. This article is distributed exclusively by the RNA Society for the first 12 months after the full-issue publication date (see http://rnajournal.cshlp.org/site/misc/terms.xhtml). After 12 months, it is available under a Creative Commons License (Attribution-NonCommercial 4.0 International), as described at http://creativecommons.org/licenses/by$\mathrm{nc} / 4.0 /$. 
RNA structure, especially when the new probe provides novel insights into RNA tertiary structure that complements existing methods.

Osmium tetroxide $\left(\mathrm{OsO}_{4}\right)$ was first used to make heavy atom derivatives of tRNA for X-ray diffraction studies (Schevitz et al. 1972) and has been used to probe DNA structures such as helical junctions (Duckett et al. 1990; Grainger et al. 1998), cruciform loops (McClellan et al. 1990), B-Z junctions (Aboul-ela et al. 1992), and structures in supercoiled DNA (Furlong et al. 1989) in vitro and in vivo (McClellan et al. 1990). Osmium tetroxide modifies the unsaturated 5-6 double bond of the thymine base (Neidle and Stuart 1976). In DNA-specific structural states such as single-stranded DNA, base mismatches, bulges, or base unstacking may change the accessibility of the unsaturated 5-6 double bond of thymines toward osmium tetroxide. Osmium tetroxide has proved to be a useful chemical probe for a number of specific DNA structures (Furlong et al. 1989; Duckett et al. 1990; McClellan et al. 1990; Aboul-ela et al. 1992; Grainger et al. 1998). The pyrimidine residues in RNA, uracil (U), and cytosine (C) contain an unsaturated 5-6 double bond (Fig. 1A); indeed, uracil in RNA (although lacking the 5-methyl group of thymine [T]) closely resembles $\mathrm{T}$ and may potentially be modified by osmium tetroxide. However, to date no study has shown that osmium tetroxide can be used as a chemical probe of RNA structure. Here we have adapted an established method for probing DNA structure with $\mathrm{OsO}_{4}$ to the probing of RNA. In this method, we show that $\mathrm{OsO}_{4}$ reacts predominantly with uracil nucleotides in structured RNAs and can detect RNA conformational changes in solution. The formation of the osmate adducts between $\mathrm{OsO}_{4}$ and uracil is detected by primer extension using a fluorescent primer and automated DNA sequencing. The principle of the assay is illustrated in Figure 1B.

A
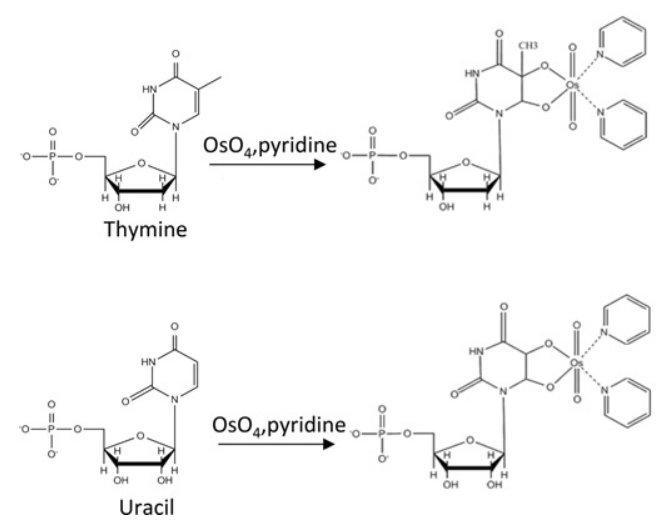

\section{RESULTS}

\section{Osmium tetroxide predominantly modifies uracil residues when the unsaturated 5-6 double bond is exposed on the external surface of RNA}

To establish $\mathrm{OsO}_{4}$ as a potential probe of RNA structure, we selected three different RNAs: the M-box riboswitch RNA, the glycine riboswitch RNA, and tRNA ${ }^{\text {Asp }}$ (Wilkinson et al. 2006; Dann et al. 2007; Wang et al. 2008). These RNAs contain a variety of tertiary structure motifs including helical RNA junctions, hairpin loops, bulged (unpaired) nucleotides, and double helical RNA, which allowed us to investigate and characterize the essential requirements for $\mathrm{OsO}_{4}$ modification of RNA. The riboswitch RNAs adopt complex tertiary structures and function through changes in RNA conformation induced by ligand binding. They provide a model system that enables us to understand how the modification of RNA by $\mathrm{OsO}_{4}$ relates to conformational changes in the RNA structure. Here we investigated $\mathrm{OsO}_{4}$ as a potential probe to study RNA structure transitions in solution.

Osmium tetroxide modification of RNA was detected by fluorescence-based capillary gel electrophoresis in the following protocol. Briefly, in vitro transcribed RNAs were folded in the appropriate buffer and incubated with $\mathrm{OsO}_{4} /$ pyridine. After ethanol precipitation, the $\mathrm{OsO}_{4}$ modified RNA was then reverse transcribed with a fluorescein (FAM)-labeled primer, and analyzed by capillary gel electrophoresis. The sites of modifications were detected by the position and incidence of abortive reverse transcripts compared to sequence markers and unmodified RNA. Sequence markers were generated by reverse transcription of the unmodified RNA in the presence of individual dideoxynucleotides.

The M-box riboswitch couples intracellular magnesium levels to the expression of bacterial metal transport genes.

\section{B}

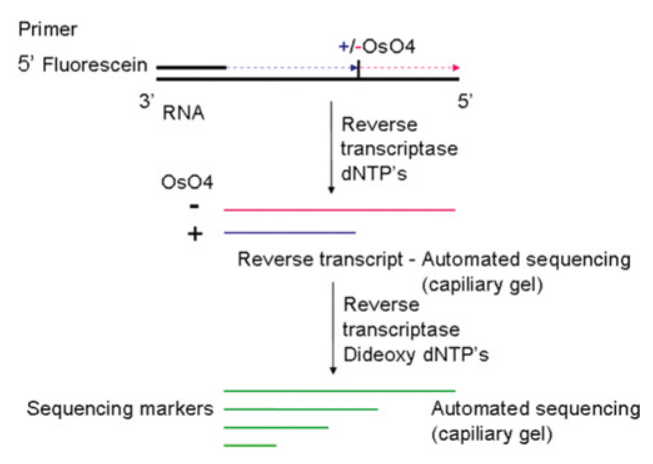

FIGURE 1. The principle of the assay; detection of osmium tetroxide modification on RNA by primer extension. (A) Osmium tetroxide modification at the 5-6 double bond of thymine in DNA and uracil in RNA generates an osmium-pyridine adduct. (B) Reverse transcription of modified RNA with a fluorescent primer leads to premature termination at the site of modification and allows automated sequencing techniques to be used to map conformationally sensitive positions on the RNA. 
We first performed reverse transcription on the M-box RNA at different $\mathrm{Mg}^{2+}$ concentrations $(0-10 \mathrm{mM})$ and in the absence of $\mathrm{OsO}_{4}$. The obtained capillary electrophoresis profiles ruled out any effect of the metal ion ligand itself on reverse transcription termination (Supplemental Fig. S1a). We carried out $\mathrm{OsO}_{4}$ modification experiments on the M-box and glycine riboswitch RNAs in the presence of ligand, and also on tRNA ${ }^{\text {Asp }}$. $\mathrm{OsO}_{4}$ modification of RNA yielded a set of electropherograms composed of a series of fluorescent peaks (Fig. 2A-C). The fluorescence signals reflect the reactivity of $\mathrm{OsO}_{4}$ modification at each nucleotide. For the M-box RNA, we detected a total of 20 fluorescent peaks, 13 of which correspond to uracils that are modified by $\mathrm{OsO}_{4}$ (Fig. 2A). The glycine riboswitch RNA sequence has a lower uracil content (13 U out of total 88 nucleotides [nt]), therefore only 6 nt were modified by $\mathrm{OsO}_{4}$ and the 4 most reactive nucleotides were uracils (Fig. $2 \mathrm{~B}$ ). In the tRNA ${ }^{\text {Asp }}$, we observed a total of 22 fluorescent peaks, 12 of which were assigned to
$\mathrm{OsO}_{4}$ modification at uracils (Fig. 2C). From the peak signals, the modified nucleotides were classified as highly reactive (greater than fivefold increase in signal intensity compared to unmodified RNA) or of intermediate reactivity (two- to fivefold increase in signal intensity relative to unmodified RNA) (Table 1). The majority of highly reactive nucleotides were uracils, although modification was also observed at $\mathrm{C}$, $\mathrm{G}$, and $\mathrm{A}$ residues. These data show that $\mathrm{OsO}_{4}$ modification predominantly takes place at the uracil residues of RNA (Table 1; Fig. 2A-C). Of the 41 uracil residues in the M-box RNA, only 19 uracils were modified by $\mathrm{OsO}_{4}$ (e.g., U113-U116, U132, U133), and some uracil residues showed no modification at all (e.g., U34, U109). Two crystal structures of the M-box RNA are available (Dann et al. 2007; Ramesh et al. 2011). Based on the crystal structures, we then compared the conformation and the surrounding environment of the uracils that were highly reactive with those that were nonreactive toward $\mathrm{OsO}_{4}$, focusing particularly

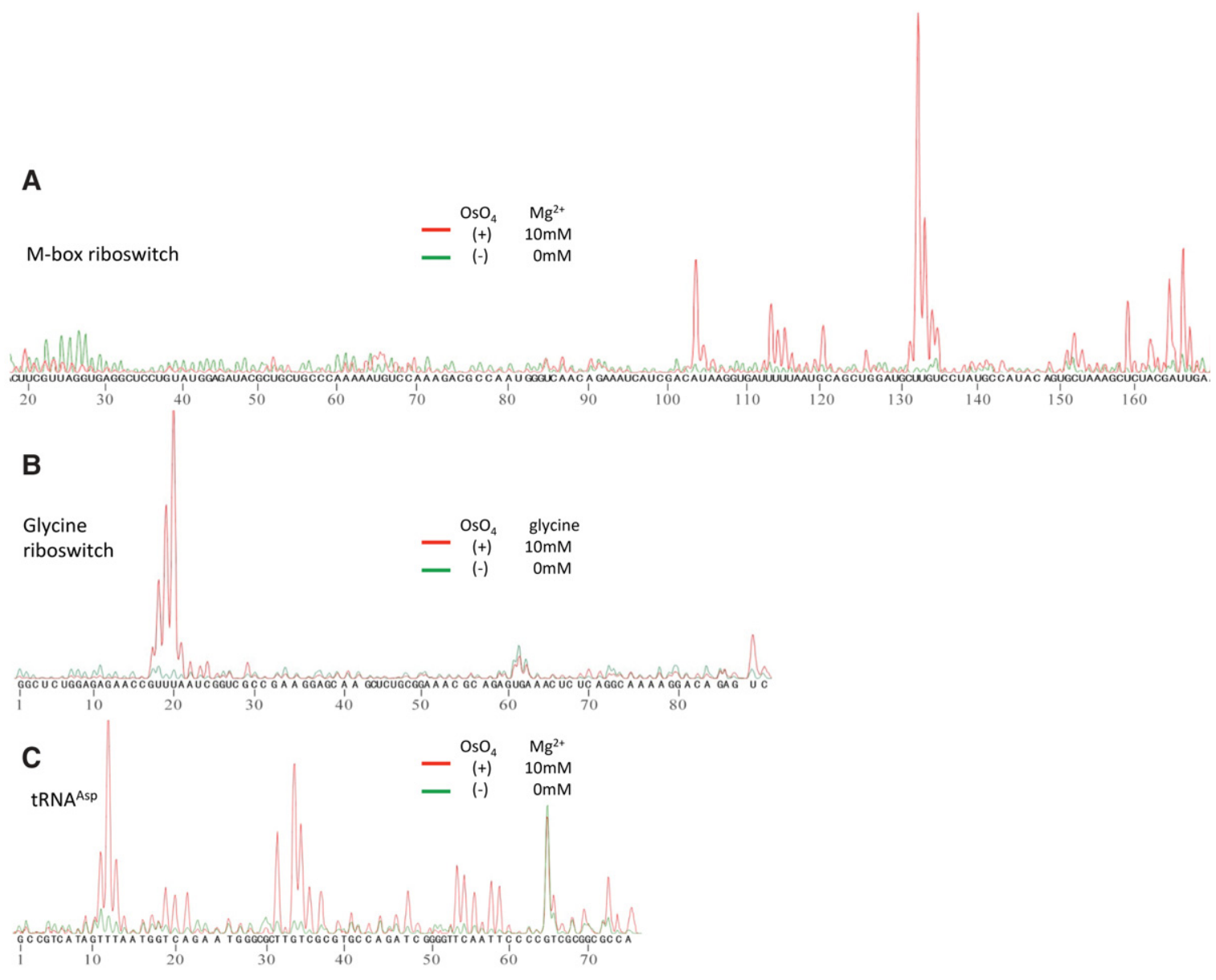

FIGURE 2. Osmium tetroxide modification of the RNAs; M-box riboswitch RNA, glycine riboswitch RNA, and tRNA ${ }^{\text {Asp }}$. (A) Electropherogram of $\mathrm{OsO}_{4}$ modification of M-box riboswitch RNA with magnesium ions; primer extension profiles are shown for OsO ${ }_{4}$ modified RNA in the presence of $10 \mathrm{mM}$ magnesium (red) compared to the unmodified RNA (green). (B) Electropherogram of $\mathrm{OsO}_{4}$ modification of glycine riboswitch RNA in the presence of added glycine; primer extension profiles are shown for $\mathrm{OsO}_{4}$ modified RNA in the presence of $10 \mathrm{mM}$ glycine (red) compared to unmodified RNA (green). (C) Electropherogram of $\mathrm{OsO}_{4}$ modification of tRNA ${ }^{\mathrm{Asp}} \mathrm{RNA}$ with magnesium ions; primer extension profiles are shown for OsO $\mathrm{O}_{4}$ modified RNA in the presence of $10 \mathrm{mM}$ magnesium (red) compared to unmodified RNA (green). 
TABLE 1. Analysis of osmium tetroxide modifications at each nucleotide in the M-box riboswitch, glycine riboswitch, and tRNA ${ }^{\text {Asp }}$ RNAs

\begin{tabular}{|c|c|c|c|c|c|}
\hline \multirow[b]{2}{*}{ RNA name } & \multirow[b]{2}{*}{ Base } & \multicolumn{2}{|l|}{ Level of modification } & \multirow{2}{*}{$\begin{array}{c}\text { Total number of } \\
\text { each base }\end{array}$} & \multirow{2}{*}{$\begin{array}{l}\text { Numbers of } \\
\text { modified base }\end{array}$} \\
\hline & & High $^{\mathrm{a}}$ & Intermediate $^{\mathrm{b}}$ & & \\
\hline \multirow[t]{4}{*}{ M-box riboswitch } & U & $\begin{array}{r}104,113,114,115,125,132 \\
133,135,153,159,166,167\end{array}$ & 116 & 41 & 13 \\
\hline & C & 131 & 152 & 33 & 2 \\
\hline & G & 120,134 & - & 38 & 2 \\
\hline & A & 103,165 & 162 & 47 & 3 \\
\hline \multirow[t]{4}{*}{ Glycine riboswitch } & $U$ & $18,19,20,87$ & 23 & 13 & 5 \\
\hline & $\mathrm{C}$ & 24 & - & 20 & 1 \\
\hline & G & - & 17,29 & 28 & 2 \\
\hline & A & 21 & 22 & 27 & 2 \\
\hline \multirow[t]{4}{*}{ tRNA } & $U$ & $11,12,13,19,32,35,47,54,58,59$ & 65 & 18 & 11 \\
\hline & $\mathrm{C}$ & $20,36,55$ & 73 & 20 & 4 \\
\hline & G & 34 & 37 & 25 & 2 \\
\hline & A & 21 & 14,56 & 12 & 3 \\
\hline
\end{tabular}

The total number of nucleotides modified, the identity, level of modification, and the position of each modified nucleotide are tabulated. The level of the osmium tetroxide modification at each position is classified as high when the signal intensity compared to the unmodified RNA increases greater than fivefold, or intermediate when the signal intensity (compared to unmodified) increases between two- and fivefold.

${ }^{a}$ Signal intensity of modified nucleotide is more than five times stronger than unmodified.

${ }^{\mathrm{b}}$ Signal intensity of modified nucleotide is between two times and five times stronger than unmodified.

on the $\mathrm{OsO}_{4}$ reactive unsaturated 5-6 double bond. We observed that for uracils that are modified by $\mathrm{OsO}_{4}$, the 5-6 double bond of the uracil (U113-U116 and U132-U133) is exposed on the surface of the folded RNA and is likely to be available for an out-of-plane attack by $\mathrm{OsO}_{4} /$ pyridine. In contrast, the 5-6 double bonds of the uracil residues that remained unmodified by $\mathrm{OsO}_{4}$ (e.g., U109) are screened by the tertiary structure of the RNA such that they are inaccessible to an out-of-plane attack by $\mathrm{OsO}_{4} /$ pyridine (Fig. $3 \mathrm{~A}$ ), and this was also the case for the glycine-sensing RNA (Fig. $3 \mathrm{~B})$. Therefore, the accessibility of the 5-6 double bond on $\mathrm{U}$ is a critical factor for $\mathrm{OsO}_{4}$ modification. We also observed a small number of $\mathrm{G}$ and $\mathrm{A}$ modifications in the M-box RNA, although the exact sites of $\mathrm{OsO}_{4}$ modification on the purines $\mathrm{G}$ and $\mathrm{A}$ are not as well characterized as for the pyrimidines and will require further investigation. Nevertheless, it is apparent that these nucleotides also occupy positions and adopt conformations that render them highly reactive toward $\mathrm{OsO}_{4}$. We observed that $\mathrm{OsO}_{4}$ also modified a small number of C's such as C131 and C152. The level of $\mathrm{OsO}_{4}$ modification at these positions was significantly smaller compared to U. Nevertheless, on examination of the crystal structures it became apparent that the main determinant for modification at $\mathrm{C}$ by $\mathrm{OsO}_{4}$ was also the accessibility of the $5-6$ double bond of the $\mathrm{C}$.

To further investigate the accessibility of bases within the M-box structure we used the program Surface Racer (Tsodikov et al. 2002). The P6 region of the M-box RNA with magnesium is disordered in the crystal and appears as a gap in the structure. We therefore used the manganesebound structure of the M-box RNA (Ramesh et al. 2011) to calculate the accessibility of bases within the M-box struc- ture. The approximate radius of the $\mathrm{OsO}_{4}$-pyridine complex is $5 \AA$ (Neidle and Stuart 1976). We used $5 \AA$ and $1.5 \AA$ radii probes to calculate the accessible surface area on the structure. We found that for the bases that were more reactive to $\mathrm{OsO}_{4}$ (U113, U114, U115, or U132), the accessible surface area remained relatively unchanged for $1.5 \AA$ and $5 \AA$ radius probes. In contrast, the bases that were unreactive to $\mathrm{OsO}_{4}$ (such as U34) showed a significant reduction in the accessible surface area using a $5 \AA$ radius probe compared to a $1.5 \AA$ radius probe (Table 2). These observations held for each monomer of the manganese-bound structure (the crystal is dimeric). This analysis provides an objective assessment of the accessibility of bases in the structure and the result is in good agreement with our $\mathrm{OsO}_{4}$ probing. A number of bases appear to adopt an "unstacked" conformation in the crystal structure although they are unreactive toward $\mathrm{OsO}_{4}$. For example, C86 at the point of strand exchange between helices $\mathrm{P} 4$ and $\mathrm{P} 5$, although ostensibly unstacked, remained unmodified by $\mathrm{OsO}_{4}$. The surface racer analysis showed that $\mathrm{C} 86$ is indeed inaccessible to the $\mathrm{OsO}_{4}$-pyridine complex (Table 2). Careful examination of the environment around C86 shows the 5-6 double bond of C86 to be oriented internally and thus completely buried and inaccessible to solvent. Similarly, U47 is located adjacent to the terminal $3^{\prime}$ end of helix P3 on the exchanging strand between helices $\mathrm{P} 2$ and $\mathrm{P} 3$ and is also not reactive to $\mathrm{OsO}_{4}$. Further analysis showed that the accessible surface of $\mathrm{U} 47$ was also shielded from the $5 \AA$ probe relative to the $1.5 \AA$ probe (Table 2). Close inspection of the position of $\mathrm{U} 47$ within the tertiary structures (Dann et al. 2007; Ramesh et al. 2011) shows that although it appears to be conformationally flexible, it adopts a series of conformations that are "sandwiched" between the ends 

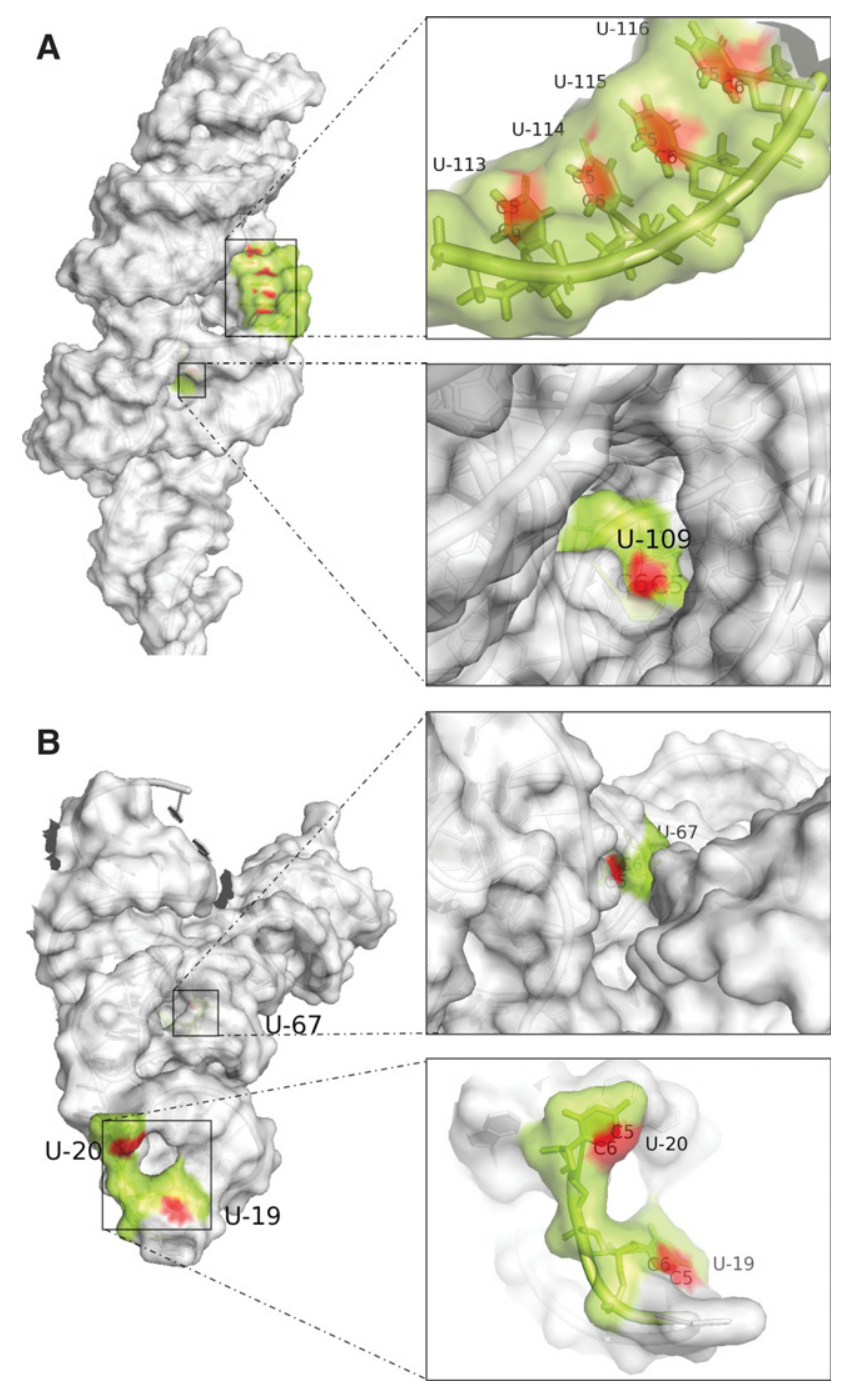

FIGURE 3. The prime determinant for $\mathrm{OsO}_{4}$ modification of RNA is the accessibility of the 5-6 double bond of uracil within the tertiary structure of the RNA. (A) The external surface of the crystal structure of the M-box RNA. The top panel denotes the local environment at the positions corresponding to $\mathrm{U} 116-\mathrm{U} 113$ with the $\mathrm{OsO}_{4}$ reactive unsaturated 5-6 double bond marked in red. Note that the 5-6 double bonds of $\mathrm{U} 116-\mathrm{U} 113$ that are modified by $\mathrm{OsO}_{4}$ are relatively exposed on the surface of the folded RNA. In contrast, the lower panel shows the unsaturated 5-6 double bond of $\mathrm{U} 109$ that is not reactive to $\mathrm{OsO}_{4}$ to be buried inside of the tertiary fold of the RNA. Graphics were generated using PyMOL (The PyMOL Molecular Graphics System, Version 1.8, Schrödinger, LLC). (B) The external surface of the crystal structure of glycine riboswitch RNA. The top panel shows the exposed 5-6 double bonds of U19-U20 in red. The unsaturated 5-6 double bonds of U19-U20 are exposed on the surface of the folded RNA and are highly modified by $\mathrm{OsO}_{4}$. The lower panel shows that the 5-6 double bond of U67 (in red) is blocked by the tertiary structure of the folded RNA so that although U67 adopts an unstacked conformation, it remains unreactive toward $\mathrm{OsO}_{4}$. Graphics were generated using PyMOL.

of helices $\mathrm{P} 2$ and $\mathrm{P} 3$ and the P6 loop in the crystal structures, such that out-of-plane electrophilic attack by the bulky $\mathrm{OsO}_{4}$-pyridine complex at the 5-6 bond of $\mathrm{U} 47$ would be impeded. These analyses therefore establish some of the criteria for $\mathrm{OsO}_{4}$ modification of RNA.

\section{Osmium tetroxide as a probe of RNA conformational change in solution}

Our data showed that $\mathrm{OsO}_{4}$ modification occurs at the unsaturated 5-6 double bond of uracil and the accessibility of the unsaturated 5-6 double bond is important for the $\mathrm{OsO}_{4}$ modification. RNA conformational changes such as base mismatches, bulges, base unstacking, or distortion at helical junctions may change the accessibility of the unsaturated 5-6 double bond of $\mathrm{U}$ or $\mathrm{C}$ to the $\mathrm{OsO}_{4}$ probe. We next investigated how $\mathrm{OsO}_{4}$ modification of the RNA reflects conformational changes in the RNA. The M-box riboswitch RNA and the glycine riboswitch RNA undergo significant conformational changes in the presence of their ligands. We therefore analyzed osmium tetroxide modification of the two riboswitch RNAs upon addition of their ligands (magnesium and glycine).

For the M-box riboswitch RNA, the electropherograms of fluorescent peaks, corresponding to the reactivity of $\mathrm{OsO}_{4}$ to the nucleotides, changed over the range of the magnesium titration. The reactivity of $\mathrm{OsO}_{4}$ to nucleotides may increase, decrease, or remain relatively unchanged in response to titration of $\mathrm{Mg}^{2+}$ (Table 3; Fig. 4A,B). The M-box RNA structure contains six helical domains (P1-6), a three-way junction (formed by P3, P4, and P5), hairpin loops, bulged (unpaired) nucleotides, and interstrand hairpin-bulge interactions, that combine to form high occupancy binding sites for magnesium ions (Dann et al. 2007). The M-box RNA structure is illustrated in Figure 4C. At low $\mathrm{Mg}^{2+}$ concentrations, high fluorescent peaks are observed at nucleotides U113-U116 (Fig. 4A; Supplemental Fig. S1b). On titration of increasing amounts of $\mathrm{Mg}^{2+}$ the reactivity of U113-U116 becomes progressively reduced (Fig. 4A,B; Supplemental Fig. S1b). Helical junctions are points at which RNA can undergo conformational changes. The nucleotides U113-U116 are located at the point of strand exchange that links helices P5 and P3 in the three-way helical junction formed by P3, P4, and P5. Helices P3 and P5 adopt an extended conformation with U113-U116 exposed at the helical junction under low $\mathrm{Mg}^{2+}$ conditions. At high $\mathrm{Mg}^{2+}$ concentrations, $\mathrm{P} 3$ and P5 become compact such that U113-U116 becomes more hidden (Fig. 4C). The reduction in reactivity to $\mathrm{OsO}_{4}$ at $\mathrm{U} 113-\mathrm{U} 116$ in response to added $\mathrm{Mg}^{2+}$ suggests that the 5-6 double bonds of $\mathrm{U} 113-\mathrm{U} 116$ are more accessible to $\mathrm{OsO}_{4}$ in the low $\mathrm{Mg}^{2+}$ conformation but become progressively less available to $\mathrm{OsO}_{4}$ in the high $\mathrm{Mg}^{2+}$ conformation. Interhelical stacking between P5 and P3 would block attack on the 5-6 double bond of $\mathrm{U} 113-\mathrm{U} 116$ by $\mathrm{OsO}_{4}$. Thus the changes in the reactivity toward the $\mathrm{OsO}_{4}$ probe at U113-U116, i.e., the accessibility of the unsaturated 5-6 double bonds of U113-U116, correlates closely with the conformational changes at the P5/P3 junction in response to changes in the $\mathrm{Mg}^{2+}$ concentration. Uracil 133 displays consistently high levels of modification by $\mathrm{OsO}_{4}$ in the presence or absence of $\mathrm{Mg}^{2+}$ and in fact the reactivity to $\mathrm{OsO}_{4}$ shows a slight 
TABLE 2. Accessible surface area (ASA) $\left(\AA^{2}\right)$ of the $\mathrm{OsO}_{4}$ reactive nucleotides on the M-box RNA

\begin{tabular}{|c|c|c|c|c|c|}
\hline & \multirow[b]{2}{*}{ Base } & \multicolumn{2}{|c|}{ Probe radius $=1.5 \AA$} & \multicolumn{2}{|c|}{ Probe radius $=5 \AA$} \\
\hline & & ASA on molecule $1^{\mathrm{a}}$ & ASA on molecule $2^{a}$ & ASA on molecule 1 & ASA on molecule 2 \\
\hline \multirow[t]{6}{*}{$\mathrm{OsO}_{4}$ reactive } & U113 & 165.6 & 171.36 & 103.38 & 93.85 \\
\hline & U114 & 178.89 & 179.19 & 133.89 & 123.82 \\
\hline & U115 & 184.13 & 179.45 & 168.3 & 162.45 \\
\hline & U129 & 179.84 & 188.74 & 113.63 & 92.79 \\
\hline & U132 & 170.55 & 202.33 & 139.11 & 188.05 \\
\hline & U133 & 192.56 & 220.67 & 295.36 & 314.74 \\
\hline \multirow[t]{4}{*}{$\mathrm{OsO}_{4}$ unreactive } & U34 & 149.89 & 157.97 & 0 & 0 \\
\hline & U109 & 93.53 & 93.51 & 0 & 0 \\
\hline & U47 & 247.34 & 237.45 & 75.6 & 87.5 \\
\hline & C86 & 188.87 & 236.03 & 12.83 & 15.19 \\
\hline
\end{tabular}

The computer program "Surface Racer" (Tsodikov et al. 2002) was used to analyze the accessibility of U's within the M-box RNA in the presence of manganese $\left(\mathrm{Mn}^{2+}\right)$ (PDB:3PDR). (Because the stem-loop P6 is disordered and appears as a gap in the magnesium $\left[\mathrm{Mg}^{2+}\right]-$ bound M-box structure, it was not suitable for analysis.) The RNA is dimeric and the accessible surface area (ASA) for each nucleotide $\left(\AA^{2}\right)$ was calculated for each monomer. By comparing the exposed surface from an initial screen using a $5 \AA$ radius probe size $(5 \AA$ is the approximate radius of the Os-pyridine complex) with a smaller $1.5 \AA$ radius probe, "buried" bases within the structure can be identified.

${ }^{a}$ The $\mathrm{Mn}^{2+}$-bound $\mathrm{M}$-box crystal structure is dimeric. The constituent RNA monomers adopt slightly different structures at some nucleotides.

increase with $\mathrm{Mg}^{2+}$. U133 is located in the terminal loop L6 of helix P6 (Fig. 4C); the consistently high levels of modification by $\mathrm{OsO}_{4}$ suggest that the $5-6$ double bond of $\mathrm{U} 133$ is freely accessible and remains a part of the loop during the RNA conformational changes upon binding of $\mathrm{Mg}^{2+}$. The small increase in reactivity at $\mathrm{U} 133$ may reflect a minor restructuring of the loop due to the global conformational change. The reactivity of U153, A154, U159, and A165 on helix P2 near the $\mathrm{Mg}^{2+}$ binding sites is progressively repressed upon $\mathrm{Mg}^{2+}$ titration as the RNA folds. At low $\mathrm{Mg}^{2+}$ concentrations, P2, P3, and P5 are openly extended with high reactivity of $\mathrm{OsO}_{4}$ toward U153, A154, U159, and A165 on P2. In contrast, at high $\mathrm{Mg}^{2+}$ concentrations, $\mathrm{P} 2, \mathrm{P} 4$, and $\mathrm{P} 5$ are folded and U153, A154, U159, and A165 on P2 consequently become more hidden and partially buried inside the folded structure, which accounts for the reduced $\mathrm{OsO}_{4}$ reactivity of these nucleotides. Similarly, the nucleotides U135-A149, $\mathrm{U} 161$, and $\mathrm{A} 162$ on $\mathrm{P} 2$ also show reduced $\mathrm{OsO}_{4}$ reactivity at high $\mathrm{Mg}^{2+}$ concentrations although the modification levels are considerably lower; this is also consistent with the idea that $\mathrm{P} 4, \mathrm{P} 5$, and $\mathrm{P} 2$ folding blocks accessibility of $\mathrm{OsO}_{4}$.

TABLE 3. Osmium tetroxide reactivity correlates with conformational changes in the M-box RNA

\begin{tabular}{lcl}
\hline Stem & \multicolumn{1}{c}{ Signal down } & \multicolumn{1}{c}{ Signal up } \\
\hline P1, P2 & G141-A165 & \multicolumn{2}{c}{-} \\
P3 & - & G120 \\
P4 & - & - \\
P5 & U113-U116, U125 & A103 \\
P6 & G134-A139 & C131, U132, U133 \\
\hline
\end{tabular}

The location and identity of nucleotides within the secondary structure of the M-box RNA that show an increase or decrease in reactivity toward osmium tetroxide on addition of $\mathrm{Mg}^{2+}$ ions.
The suppression of reactivity at nucleotides along the length of helix P2 reflects that P4 and P5 fold onto P2, which plays an important role in the assembly of the $\mathrm{Mg}^{2+}$ ion-bound M-box RNA. $\mathrm{OsO}_{4}$ reactivities are generally reduced upon $\mathrm{Mg}^{2+}$ titration, reflecting the change in conformation of the M-box RNA from an extended to a compact structure (Fig. 4C; Supplemental Fig. S2). The changes in $\mathrm{OsO}_{4}$ reactivity correlate with the known conformational changes of the M-box RNA.

For the glycine riboswitch RNA, upon $\mathrm{OsO}_{4}$ modification the electropherograms of the fluorescent peaks only change at positions U19-U20 in the presence or absence of glycine (Supplemental Fig. S1c). The fluorescent signals at U19U20, which are located in a stem loop, increased progressively on titration with glycine. In the absence of glycine, the riboswitch RNA with the U19-U20 loop may adopt an intermediate prefolded structure. However, analysis of the glycine riboswitch structures (Huang et al. 2010) showed that upon glycine binding, the RNA adopts a compact conformation in which U19-U20 in the stem-loop are unstacked and become particularly accessible to an out-of-plane attack by $\mathrm{OsO}_{4}$. This explains the changes in the $\mathrm{OsO}_{4}$ reactivity at $\mathrm{U} 19$ $\mathrm{U} 20$ with or without glycine. The increase in $\mathrm{OsO}_{4}$ reactivity in the loop at U19-U20 on glycine binding is somewhat similar to the increase in reactivity at U133 in the P6 loop of the M-box RNA on magnesium ion binding, suggesting that these loops undergo further minor structural rearrangements upon ligand binding.

\section{DISCUSSION}

We have shown that osmium tetroxide can be used as a reliable probe to study RNA tertiary structure and RNA conformational changes in solution. The following evidence 


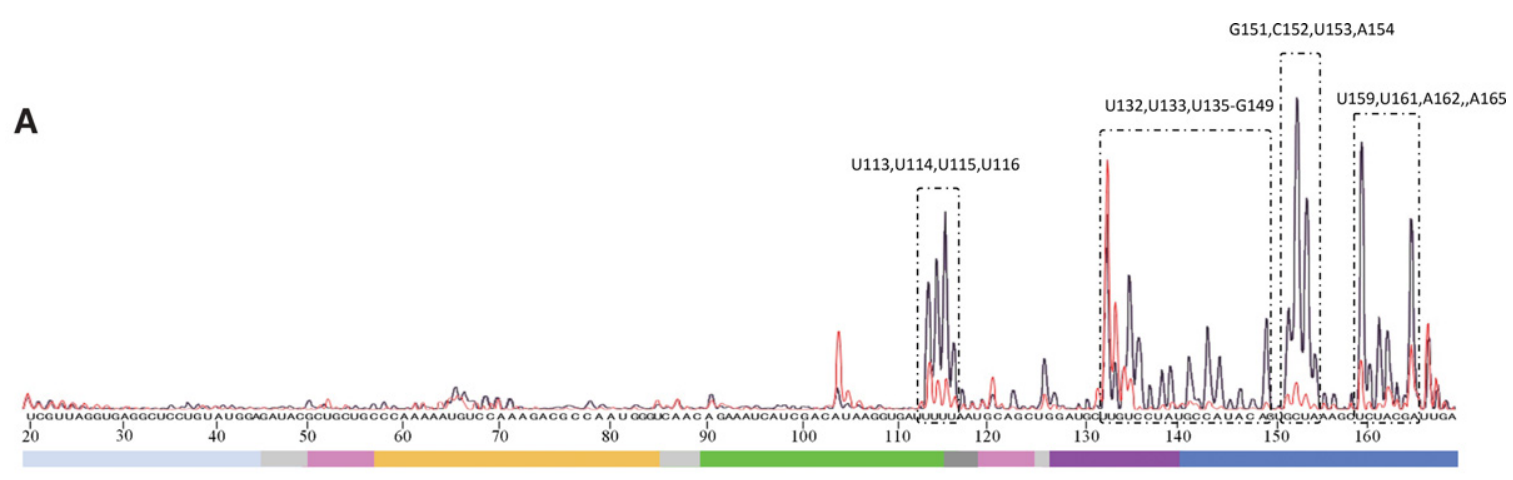

$\mathbf{B}$

C

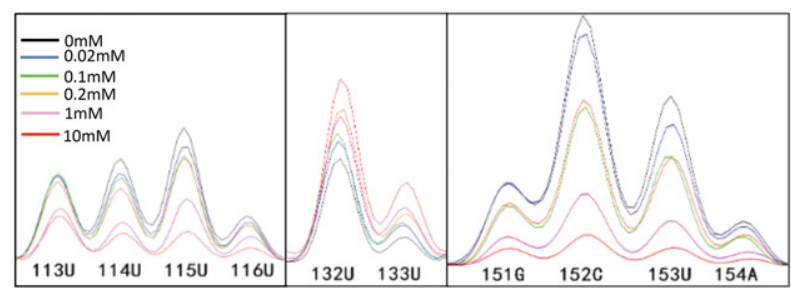

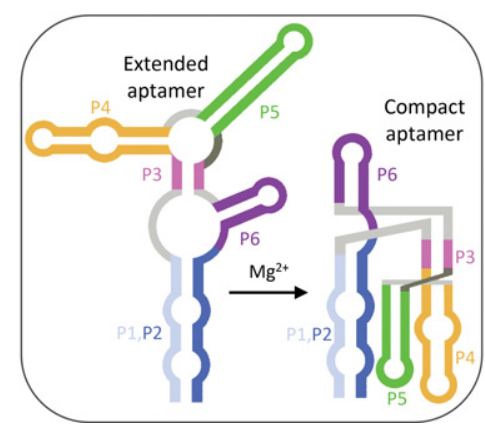

FIGURE 4. The relationship between osmium tetroxide reactivity and conformational transitions in the M-box RNA. (A) The electropherograms of fluorescent peaks of the M-box RNA in the absence of magnesium ions (black) and the presence of $10 \mathrm{mM}$ magnesium ions (red). The nucleotides corresponding to each fluorescent peak are indicated; for clarity, the positions of multiple peaks that show significant changes are boxed. The colored bar represents the strands of the helical domains of the folded RNA secondary structure denoted in $C$. $(B)$ The electropherograms of the fluorescent peaks for nucleotides U113-116, U132-U133, or G151-A154 of the M-box RNA upon titration of magnesium ions $(0,0.02,0.1,0.2,1,10 \mathrm{mM})$. (C) A cartoon of the secondary structure transition of the M-box RNA on the addition of magnesium. The constituent strands of the folded RNA correspond to the colored bar shown in A. Component helical stems are labeled P1-P6.

supports our conclusions: First, we have used three known structured RNAs to characterize osmium tetroxide modification to RNA and establish the principles of RNA modification by $\mathrm{OsO}_{4}$. We show that osmium tetroxide modification of RNA predominantly takes place at uracil nucleotides under conditions where the unsaturated 5-6 double bond of $U$ is exposed on the surface of the RNA. Consequently, the availability and relative reactivity of osmium tetroxide toward the unsaturated 5-6 double bond of $U$ can be diagnostic of the tertiary folding of the RNA structure in solution. Secondly, we used osmium tetroxide to probe the M-box and glycine riboswitch RNAs upon titration of their ligands to test whether RNA conformational changes in solution could be detected by $\mathrm{OsO}_{4}$ modification. The changes in the reactivity toward $\mathrm{OsO}_{4}$ of specific nucleotides within the riboswitch RNAs were found to be consistent with the established RNA conformational transitions for both riboswitch RNAs. Thus, osmium tetroxide is a valuable probe for RNA conformational changes.

The crystal structures of the M-box and glycine riboswitch RNAs enabled us to compare the chemical environment of the reactive positions within the nucleotides that were modified by osmium tetroxide and allowed us to establish the conditions for $\mathrm{OsO}_{4}$ modification of RNA. Although the crystal structures have enabled us to identify the important requirements for RNA modification by $\mathrm{OsO}_{4}$, the application of this method and the interpretation of the data can be completely independent of high-resolution structures. Osmium tetroxide probing may provide valuable information when such structures are not available, or when folding intermediates prove refractory to high-resolution techniques.

Osmium tetroxide is a valuable chemical probe for DNA structures (Furlong et al. 1989; Duckett et al. 1990; McClellan et al. 1990; Aboul-ela et al. 1992; Grainger et al. 1998). Although $\mathrm{OsO}_{4}$ predominantly reacts with unstacked thymine bases in DNA, it has also been reported to modify guanines under particular conditions (in the presence of $\mathrm{CaCl}_{2}$ [Dobi et al. 1994]). Compared to $\mathrm{OsO}_{4}$ modification of DNA, we observe that $\mathrm{OsO}_{4}$ also modifies pyrimidines, primarily at the thymine analog uracil although cytosine is also modified to a lesser extent and modifications are also observed at guanine and adenine nucleotides, mostly at lower levels. The modification by $\mathrm{OsO}_{4}$ of cytosine probably takes place at the unsaturated pyrimidine 5-6 double bond as well. The sites of modification by $\mathrm{OsO}_{4}$ on the purines have yet to be determined and require further investigation.

Genome-wide analysis of RNA structure has been initiated through the development of high-throughput methods for 
RNA structure determination by specific enzymes (Kertesz et al. 2010) or chemical probes (Ding et al. 2014; Rouskin et al. 2014; Spitale et al. 2015). These methods enable determination of RNA secondary structures on a genomic scale simultaneously in one experiment (Mortimer et al. 2014; Kwok et al. 2015; Lu and Chang 2016). We have used fluorescence-based capillary electrophoresis sequencing techniques to detect $\mathrm{OsO}_{4}$ modification of structured RNAs. This method has potential for high sample capacities and can be further developed into a high-throughput method using $\mathrm{OsO}_{4}$ as a probe for genome-wide investigation of RNA structure. Osmium tetroxide has been shown to modify DNA in situ (Rahmouni and Wells 1989; McClellan et al. 1990) and is also a potential probe of RNA structure inside cells.

In general, probing a structured RNA with the $\mathrm{OsO}_{4}{ }^{-}$ pyridine complex can contribute structural information about the RNA of interest at two levels: It can provide information on ligand-dependent RNA folding, and also information on the conformations and solvent accessibility of particular nucleobases in the folded RNA. Nucleotides that experience significant changes in reactivity either through an increase or decrease in modification upon ligand binding are likely to sample conformations that become open or closed to out-of-plane nucleophilic attack. A number of structured motifs can be identified within the RNA, including stem-loops, helical junctions, and mispaired bases. Because long structured RNAs like the M-box RNA tend to fold to minimize solvent accessibility to the RNA, in their folded form the reactive bonds tend to be located on the outside of the helix in the major groove with the reactive bond facing outwards.

As a chemical probe $\mathrm{OsO}_{4}$ presents a number of clear points of difference to existing chemical probes. The primary site of modification in RNA is the 5-6 double bond of uracil on the major groove side of the RNA, secondary sites of modification also occur at the analogous position on cytosine, and modifications may also take place at purine nucleotides, mostly at low levels. Because uracil is the main site of $\mathrm{OsO}_{4}$ modification, the probing data are relatively simple to interpret. Osmium tetroxide, in combination with phylogenetic data and predictive computational folding methods, may be used to analyze the folding and secondary structure of novel regulatory RNAs at nucleotide resolution. Osmium tetroxide as a chemical probe of RNA tertiary structure provides novel information that complements existing methods.

\section{MATERIALS AND METHODS}

\section{RNA synthesis and purification}

The RNAs were prepared by in vitro transcription using T7 RNA polymerase. T7 promoter sequence was included in the primer sequence. The primer sequence and the template sequence for the in vitro transcription of the three RNAs can be found in Supplemental File 3S. The in vitro transcription containing 2.5 $\mathrm{mM}$ rNTPs, $1 \times$ transcription buffer $(40 \mathrm{mM}$ Tris- $\mathrm{HCl}, \mathrm{pH} 7.9$, $0.01 \%$ [v/v] Triton X-100, $20 \mathrm{mM} \mathrm{MgCl}_{2}, 2 \mathrm{mM}$ spermidine), 10 mM DTT, 500 ng-5 $\mu \mathrm{g}$ DNA template, $100 \mathrm{U}$ of RNase Inhibitor, and $250 \mathrm{U}$ of T7 RNA polymerase in a total of $100 \mu \mathrm{L}$ was incubated at $42^{\circ} \mathrm{C}$ for $4-5 \mathrm{~h}$. DNA template was digested by adding $10 \mathrm{U}$ DNase I at $37^{\circ} \mathrm{C}$ for $45 \mathrm{~min}$. RNA was then gel purified by $10 \%$ denaturing polyacrylamide gel electrophoresis extracted by electroelution and recovered by ethanol precipitation. RNA samples were incubated in buffer (50 mM Tris- $\mathrm{HCl}[\mathrm{pH} 8], 100 \mathrm{mM} \mathrm{KCl}$ ) at $65^{\circ} \mathrm{C}$ for 5 min and then cooled to room temperature.

\section{$\mathrm{OsO}_{4}$ probing}

Approximately 20 pmol of RNA was incubated in buffer $(50 \mathrm{mM}$ Tris- $\mathrm{HCl}[\mathrm{pH} 8], 100 \mathrm{mM} \mathrm{KCl}$ ) containing the desired concentration of $\mathrm{MgCl}_{2}$ in a total volume of $10 \mu \mathrm{L}$ in an eppendorf tube. RNA was modified with $\mathrm{OsO}_{4} /$ pyridine at a final concentration of $1 \mathrm{mM} / 0.76 \mathrm{mM}$ at $25^{\circ} \mathrm{C}$ for $1 \mathrm{~h}$ (Lukásová et al. 1984; Duckett et al. 1990; Aboul-ela et al. 1992). The reaction was stopped by ethanol precipitation and the RNA was recovered and taken up in reverse transcriptase buffer (first-strand synthesis buffer: $50 \mathrm{mM}$ Tris- $\mathrm{HCl}[\mathrm{pH} 8.3$ at room temperature], $75 \mathrm{mM} \mathrm{KCl}, 3 \mathrm{mM}$ $\mathrm{MgCl}_{2}, 0.01 \mathrm{M} \mathrm{DTT}, 40 \mathrm{U}$ [RNase inhibitor]) for $20 \mu \mathrm{L}$ reverse transcription reactions. The control sample $\left(-\mathrm{OsO}_{4}\right)$ was not treated with $\mathrm{OsO}_{4}$ /pyridine for modification, but was otherwise treated identically to the $\mathrm{OsO}_{4} /$ pyridine modified sample. N.B. Both $\mathrm{OsO}_{4}$ and pyridine are highly toxic chemicals. Concentrated stock solutions of $\mathrm{OsO}_{4}$ were stored in glass vials. Reactions were performed in a fume hood and gloves, eye protection, and a laboratory coat worn at all times. Material Safety Data Sheet information is available at http://www.sigmaaldrich.com.

\section{The first-strand cDNA synthesis (FSS) and sequencing}

The fluorescein (FAM)-labeled primer sequence (Watts et al. 2009) is given in S5. For each RNA sample an FSS reaction was prepared by mixing $5 \mu \mathrm{L}$ of the modified RNA in TE buffer, 2 pmol FAM-specific primer, 10 pmol dNTPs in $13 \mu \mathrm{L}$. Sequencing markers were prepared in parallel from unmodified RNA, FAM-specific primer, 10 pmol dNTPs, and 40 pmol ddNTPs. The mixture was incubated at $65^{\circ} \mathrm{C}$ for $5 \mathrm{~min}$; then cooled on ice for $1 \mathrm{~min}$ to anneal the RNA and primer. For all reverse transcription reactions first-strand synthesis buffer (50 mM Tris- $\mathrm{HCl}$ [ $\mathrm{pH} 8.3$ at room temperature], $75 \mathrm{mM} \mathrm{KCl}, 3 \mathrm{mM} \mathrm{MgCl} 2,0.01 \mathrm{M} \mathrm{DTT}, 40 \mathrm{U}$ RNase inhibitor) was added and cDNA synthesis initiated by adding 200 U Superscript III reverse transcriptase to a final volume of $20 \mu \mathrm{L}$, and the reaction was incubated at $55^{\circ} \mathrm{C}$ for $60 \mathrm{~min}$. Reverse transcription was terminated by addition of $1 \mu \mathrm{L} 4 \mathrm{M} \mathrm{NaOH}$ and heating at $95^{\circ} \mathrm{C}$ for $5 \mathrm{~min}, \mathrm{cDNAs}$ were recovered by ethanol precipitation and the pellet resuspended in $5 \mu \mathrm{L}$ water. cDNA samples were analyzed with an ABI 3730xl DNA analyzer.

\section{Data processing}

Electropherograms of cDNAs corresponding to the modified and unmodified RNA samples and sequence markers were analyzed using peak scanner software (v1.0) (ABI). Raw capillary 
electropherograms were normalized using the Sizing Default analysis method provided with the peak scanner software. The positions of premature termination of primer extension at modified nucleotides were identified by manual alignment with the sequence markers. Normalized electropherogram plots of the modified samples were compared with the unmodified samples through nucleotide position alignment.

\section{Surface racer analysis}

The computer program Surface Racer (Tsodikov et al. 2002) was downloaded from: (http://pharmacy.uky.edu/research-innovationand-discovery/faculty-labs/tsodikov-laboratory/software) and was used to analyze the accessibility of the nucleotides within the M-box RNA in the presence of manganese (PDB:3PDR). The accessible surface area (ASA) for each nucleotide $\left(\AA^{2}\right)$ was calculated by using $5 \AA$ and $1.5 \AA$ radius probes $(5 \AA$ is the approximate radius of the $\mathrm{OsO}_{4}$-pyridine complex).

\section{SUPPLEMENTAL MATERIAL}

Supplemental material is available for this article.

\section{ACKNOWLEDGMENTS}

We thank $\mathrm{Gu}$ Zhongkai for assistance with capillary sequencing and members of our laboratory for discussion. This work was supported by National Key Research and Development Project of China (2016YFA0500600), National Science Foundation (NSF) 31400050 to J.Z.; 31370107 to D.C.; 31330022 and 31420103907 to A.M.; City of Shanghai Natural Science Foundation for Young Scientists 13ZR1451600 to J.Z.; and City of Shanghai Chen Guang Plan to J.Z.

Received May 17, 2016; accepted January 9, 2017.

\section{REFERENCES}

Aboul-ela F, Bowater RP, Lilley DM. 1992. Competing B-Z and helixcoil conformational transitions in supercoiled plasmid DNA. J Biol Chem 267: 1776-1785.

Ambros V. 2001. microRNAs: tiny regulators with great potential. Cell 107: 823-826.

Cruz JA, Westhof E. 2009. The dynamic landscapes of RNA architecture. Cell 136: 604-609.

Dann CE III, Wakeman CA, Sieling CL, Baker SC, Irnov I, Winkler WC. 2007. Structure and mechanism of a metal-sensing regulatory RNA. Cell 130: 878-892.

Dethoff EA, Chugh J, Mustoe AM, Al-Hashimi HM. 2012. Functional complexity and regulation through RNA dynamics. Nature 482: 322-330.

Ding Y, Tang Y, Kwok CK, Zhang Y, Bevilacqua PC, Assmann SM. 2014. In vivo genome-wide profiling of RNA secondary structure reveals novel regulatory features. Nature 505: 696-700.

Dobi AL, Matsumoto K, Santha E, v Agoston D. 1994. Guanine specific chemical sequencing of DNA by osmium tetroxide. Nucleic Acids Res 22: 4846-4847.

Duckett DR, Murchie AI, Lilley DM. 1990. The role of metal ions in the conformation of the four-way DNA junction. EMBO $J$ 9: 583-590.
Furlong JC, Sullivan KM, Murchie AI, Gough GW, Lilley DM. 1989. Localized chemical hyperreactivity in supercoiled DNA: evidence for base unpairing in sequences that induce low-salt cruciform extrusion. Biochemistry 28: 2009-2017.

Grainger RJ, Murchie AI, Lilley DM. 1998. Exchange between stacking conformers in a four-way DNA junction. Biochemistry 37: 23-32.

Guttman M, Amit I, Garber M, French C, Lin MF, Feldser D, Huarte M, Zuk O, Carey BW, Cassady JP, et al. 2009. Chromatin signature reveals over a thousand highly conserved large non-coding RNAs in mammals. Nature 458: 223-227.

Huang L, Serganov A, Patel DJ. 2010. Structural insights into ligand recognition by a sensing domain of the cooperative glycine riboswitch. Mol Cell 40: 774-786.

Kapranov P, Cheng J, Dike S, Nix DA, Duttagupta R, Willingham AT, Stadler PF, Hertel J, Hackermüller J, Hofacker IL, et al. 2007. RNA maps reveal new RNA classes and a possible function for pervasive transcription. Science 316: 1484-1488.

Kenyon J, Prestwood L, Lever A. 2014. Current perspectives on RNA secondary structure probing. Biochem Soc Trans 42: 12511255.

Kertesz M, Wan Y, Mazor E, Rinn JL, Nutter RC, Chang HY, Segal E. 2010. Genome-wide measurement of RNA secondary structure in yeast. Nature 467: 103-107.

Kwok CK, Tang Y, Assmann SM, Bevilacqua PC. 2015. The RNA structurome: transcriptome-wide structure probing with next-generation sequencing. Trends Biochem Sci 40: 221-232.

Lu Z, Chang HY. 2016. Decoding the RNA structurome. Curr Opin Struct Biol 36: 142-148.

Lukásová E, Vojtísková M, Jelen F, Sticzay T, Palecek E. 1984. Osmiuminduced alteration in DNA structure. Gen Physiol Biophys 3: 175-191.

Mauger DM, Weeks KM. 2010. Toward global RNA structure analysis. Nat Biotechnol 28: 1178-1179.

McClellan JA, Boublíková P, Palecek E, Lilley DM. 1990. Superhelical torsion in cellular DNA responds directly to environmental and genetic factors. Proc Natl Acad Sci 87: 8373-8377.

Mortimer SA, Kidwell MA, Doudna JA. 2014. Insights into RNA structure and function from genome-wide studies. Nat Rev Genet 15: 469-479.

Neidle S, Stuart DI. 1976. The crystal and molecular structure of an osmium bispyridine adduct of thymine. Biochim Biophys Acta 418: 226-231.

Rahmouni AR, Wells RD. 1989. Stabilization of Z DNA in vivo by localized supercoiling. Science 246: 358-363.

Ramesh A, Wakeman CA, Winkler WC. 2011. Insights into metalloregulation by M-box riboswitch RNAs via structural analysis of manganese-bound complexes. J Mol Biol 407: 556-570.

Rouskin S, Zubradt M, Washietl S, Kellis M, Weissman JS. 2014. Genome-wide probing of RNA structure reveals active unfolding of mRNA structures in vivo. Nature 505: 701-705.

Schevitz RW, Navia MA, Bantz DA, Cornick G, Rosa JJ, Rosa MD, Sigler PB. 1972. An isomorphous heavy-atom derivative of crystalline formylmethionine transfer RNA. Science 177: 429-431.

Shcherbakova I, Mitra S, Beer RH, Brenowitz M. 2006. Fast Fenton footprinting: a laboratory-based method for the time-resolved analysis of DNA, RNA and proteins. Nucleic Acids Res 34: e48.

Soukup GA, Breaker RR. 1999. Relationship between internucleotide linkage geometry and the stability of RNA. RNA 5: 1308-1325.

Spitale RC, Flynn RA, Zhang QC, Crisalli P, Lee B, Jung J-W, Kuchelmeister HY, Batista PJ, Torre EA, Kool ET, et al. 2015. Structural imprints in vivo decode RNA regulatory mechanisms. Nature 519: 486-490.

Tijerina P, Mohr S, Russell R. 2007. DMS footprinting of structured RNAs and RNA-protein complexes. Nat Protoc 2: 2608-2623.

Tsodikov OV, Record MT, Sergeev YV. 2002. Novel computer program for fast exact calculation of accessible and molecular 


\section{Zhang et al.}

surface areas and average surface curvature. J Comput Chem 23: 600-609.

Tullius TD, Greenbaum JA. 2005. Mapping nucleic acid structure by hydroxyl radical cleavage. Curr Opin Chem Biol 9: 127-134.

Wang B, Wilkinson KA, Weeks KM. 2008. Complex ligand-induced conformational changes in tRNA ${ }^{\text {Asp }}$ revealed by single-nucleotide resolution SHAPE chemistry. Biochemistry 47: 3454-3461.

Watts JM, Dang KK, Gorelick RJ, Leonard CW, Bess JW Jr, Swanstrom R, Burch CL, Weeks KM. 2009. Architecture and secondary structure of an entire HIV-1 RNA genome. Nature 460: 711-716.
Weeks KM. 2010. Advances in RNA structure analysis by chemical probing. Curr Opin Struct Biol 20: 295-304.

Westhof E, Romby P. 2010. The RNA structurome: high-throughput probing. Nat Methods 7: 965-967.

Wilkinson KA, Merino EJ, Weeks KM. 2006. Selective 2'-hydroxyl acylation analyzed by primer extension (SHAPE): quantitative RNA structure analysis at single nucleotide resolution. Nat Protoc 1: 1610-1616.

Xu Z, Culver G. 2013. RNA structure experimental analysis—chemical modification. Methods Enzymol 530: 363-380. 

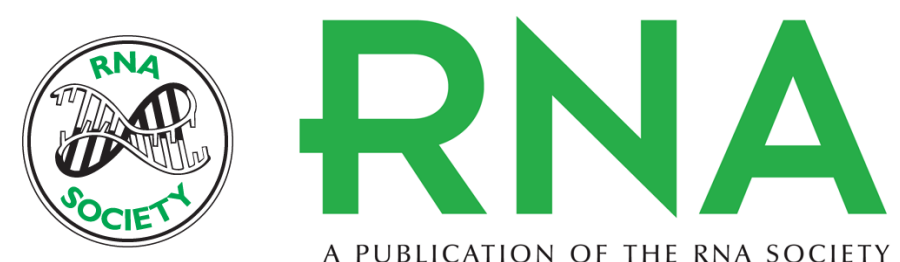

A PUBLICATION OF THE RNA SOCIETY

\section{Osmium tetroxide as a probe of RNA structure}

Jing Zhang, Danbin Li, Jun Zhang, et al.

RNA 2017 23: 483-492 originally published online January 23, 2017

Access the most recent version at doi:10.1261/rna.057539.116

Supplemental Material

References

Creative Commons License

Email Alerting Service
http://rnajournal.cshlp.org/content/suppl/2017/01/23/rna.057539.116.DC1

This article cites 38 articles, 7 of which can be accessed free at: http://rnajournal.cshlp.org/content/23/4/483.full.html\#ref-list-1

This article is distributed exclusively by the RNA Society for the first 12 months after the full-issue publication date (see http://rnajournal.cshlp.org/site/misc/terms.xhtml). After 12 months, it is available under a Creative Commons License (Attribution-NonCommercial 4.0 International), as described at http://creativecommons.org/licenses/by-nc/4.0/.

Receive free email alerts when new articles cite this article - sign up in the box at the top right corner of the article or click here.

To subscribe to $R N A$ go to:

http://rnajournal.cshlp.org/subscriptions 